\title{
Dynamics of Maritime Terrorist Threats to Russia and the Government's Response
}

\author{
Simon Saradzhyan *
}

\section{Introduction}

Russia has been the victim of a number of horrendous terrorist attacks at the hands of endemic actors, such as networks of radical separatists and terrorists based in the North Caucasus. These networks have bombed a Coast Guard residential complex and a parade at a Caspian Sea town, killing dozens; they have plotted to hijack one atomic submarine and claimed responsibility for sinking another; and their supporters seized a vessel with Russian passengers on board and threatened to blow it up. Some groups within these networks have already crossed the moral threshold between conventional and catastrophic terrorism by staging such horrendous attacks as the hostage taking in Beslan, in which 331 people, half of them children, were killed in 2004. The hostagetaking raids on the Beslan school and on Moscow's Dubrovka Theater in 2002 demonstrated the formidable capabilities of these networks in planning and executing complex attacks, which involved profound knowledge of the practical flaws and organizational deficiencies of Russia's counter-terrorism and law-enforcement system. Attackers in both cases included individuals willing to die in the course of the attacks.

The Russian authorities have dealt these networks a number of serious blows thanks to the strengthening of the Russian state and its security and law-enforcement apparatus, as well as to the increased involvement of local populations, including former rebels, in counter-insurgency and policing efforts. They have also significantly improved the security of critical facilities of land-based infrastructure, such as nuclear power plants and nuclear weapons facilities. Nevertheless, the security at some Russian facilities, including maritime facilities, remains insufficient to withstand an assault by a well-organized terrorist group similar to those that attacked the Beslan school and Dubrovka Theater, especially if it was assisted by insiders. These networks remain not

Simon Saradzhyan is a research fellow at the Belfer Center at Harvard University's Kennedy School of Government. Prior to joining the Belfer Center, he worked as deputy editor of the Moscow Times and as a consultant for the United Nations Office for the Coordination of Humanitarian Affairs (OCHA). Parts of this essay are based on the chapter "Russia's System to Combat Terrorism and Its Application in Chechnya" in National Counter-Terrorism Strategies. Legal, Institutional, and Public Policy Dimensions in the US, UK, France, Turkey and Russia, ed. Robert W. Orttung and Andrey Makarychev (Amsterdam: IOS Press, 2006), 176-190, and on "Russia: Grasping Reality of Nuclear Terror," Annals of the American Academy of Political and Social Science 607:1 (September 2006): 64-77. 
only willing, but also capable of executing terrorist attacks in Russia with high impact and dramatic visibility. ${ }^{1}$

These trends suggest that the likelihood of a high-impact maritime terrorist attack in Russia is significant enough to require that policymakers in the sphere of counterterrorism divert some of their attention from land to seas and rivers. This paper begins by identifying those actors that have the capacity and motivation to commit acts of maritime terrorism against Russia. The article then reviews Russia's maritime and freshwater infrastructure and activities before outlining selected scenarios of terrorist acts that could take advantage of vulnerabilities in this infrastructure and facilities. It then offers an overview of the Russian government's response to terrorism, including the flaws that have existed in this response. The paper concludes that the threat of maritime terrorism, including catastrophic terrorism, remains serious, and offers selected recommendations on how to minimize the likelihood of such attacks.

\section{Agents of Terror}

\section{Networks of Radical Separatists Based in the North Caucasus}

Of all the agents plotting and executing acts of terror in Russia, terrorist networks based in the North Caucasus have the strongest motivation and greatest capabilities for acts of maritime terrorism, possibly of catastrophic proportions. As demonstrated by some of their previous attacks, these networks are prepared to inflict massive, indiscriminate casualties, making no distinction between state or civilian targets. ${ }^{2}$

Until several years ago, the Chechnya-based factions of these terror networks had been the most active, even displaying interest in acts of WMD terrorism. They ac-

1 The nature and motivation of conventional guerilla and terrorist networks operating in the North Caucasus varies greatly. These include groups and individuals who fight for the establishment of an Islamic state in parts of the entire North Caucasus and groups and individuals who fight for a secular independent state of Chechnya or larger parts of the North Caucasus. For purposes of clarity, I refer to these groups as radical separatists. The line between these networks is often blurred, and some members switch from one to another. There are other groups that use violence against authority and enter into alliances with radical separatists but do not fit the criteria of radical separatists, such as organized crime syndicates and groups of avengers, who seek revenge for abuses by law enforcement and other government agencies.

2 This article defines a terrorist act as an act of political violence that inflicts harm on noncombatants, but that is designed to intimidate broader audiences, including state authorities, and is an instrument used to achieve certain political or other goals. This article defines an act of catastrophic terrorism as a terrorist attack involving the use of chemical, biological, or nuclear materials or weapons of mass destruction, or conventional techniques to kill a significant number of people (1000 or more). 
quired radioactive materials, ${ }^{3}$ threatened to attack Russia's nuclear facilities, ${ }^{4}$ and attempted to put pressure on the Russian leadership by planting a container with radioactive materials in Moscow and threatening to detonate it. ${ }^{5}$ They also planted explosives in chemical storage tanks and scouted Russian military nuclear facilities. ${ }^{6}$

But their most stunning plot relates to maritime terrorism. This plan was uncovered in January 2002, when federal troops found the personal archive of the Chechen separatists' late president Dzhokhar Dudayev. The archive, which was found in the Chechen village of Starye Atagi on 4 January 2002, contained a detailed plan to hijack a Russian atomic submarine. The commander of the Russian troops in Chechnya, Vladimir Moltenskoi, told reporters on 2 February 2002 that the plan provided for seven Slavic-looking fighters to seize a submarine from the Russian Navy's Pacific Fleet sometime in 1995-96, and to blackmail Moscow into withdrawing troops from Chechnya and recognizing the republic as an independent state. Moltenskoi said detailed military maps of Primorskii Krai, where the Pacific Fleet has bases, were found along with the plan. According to an April 2002 Russian television report, the plan specifi-

3 Chechen rebels removed several containers of radioactive materials from the Grozny branch of Russia's Radon nuclear waste collection site prior to the seizure of the facility by federal troops in January 2000, according to a Russian magazine's sources in the Russian Ministry of Defense. Yury Gladkevich, "Poshel v Gory," Profil (20 March 2000), quoted in "Radwaste Reported Removed from Radon Facility in Grozny," NIS Nuclear Trafficking Database, Center for Nonproliferation Studies, Monterey Institute of International Studies Nuclear Threat Initiative; available at www.nti.org/db/nistraff/2000/20000230.htm.

4 Then-Chechen president Dzhokhar Dudayev warned that his fighters might attack nuclear plants in Russia in 1992 to discourage Moscow from trying to counter his republic's independence bid. He issued a similar threat again in 1995 when the military campaign was already underway in the republic. "Dudayev Grozit Perenesti Voinu v Glub' Rossii," Vecherny Chelyabinsk (1 February 1995).

5 Chechen warlord Shamil Basayev tried to blackmail the Russian leadership with a crude radiological device. Basayev began with threats to organize undercover attacks with radioactive, chemical, and biological substances against Moscow and other strategic sites in Russia unless peace negotiations, which began on 5 July 1995, proved successful. In late July the talks failed, and four months later — on 23 November 1995 - a Russian TV crew found a lead container filled with radioactive cesium-137, which had been planted by Basayev's men, in Moscow's Izmailovsky Park. In addition to tipping off the media, Basayev also claimed that his agents had smuggled in four more such packages, and that at least two of them contained explosives, which could be detonated at any time, turning the containers into "dirty bombs." Grigorii Sanin and Aleksandr Zakharov, "Konteyner Iz Izmailovskogo Parka Blagopoluchno Evakuirovan," Segodnya (25 November 1995).

6 A specially equipped cache containing a cyanide-based substance was discovered during the course of combat in an unnamed settlement on the Chechen-Ingush border. "Experts have concluded that the application of these strong-acting poisons in minimal doses in crowded places, in vital enterprises, and in water reservoirs could produce numerous victims," the FSB said. "According to experts, the contents of a single 4-gram container could kill around 100 people." "FSB Says Major Terror Attacks Foiled," Moscow Times (6 May 2005). 
cally provided for taking a nuclear warhead from the hijacked submarine to Chechnya. A Chechnya-based correspondent of Russian State Television quoted what he described as the "last item" in the plan as saying "together with the hostage(s) ... and the nuclear warhead they will leave for Chechnya in a plane. ${ }^{\prime 8}$ It was a former officer in the Soviet Navy, Islam Khasukhanov, who allegedly developed the plan back in 1995. According to Moltenskoi, the then-chief of the Chechen General Staff Aslan Maskhadov personally reviewed the plan and wrote notes on it. Federal troops seized Khasukhanov during a raid in the Chechen town of Shali on 21 April 2002. Khasukhanov had served on Russian submarines before leaving the Pacific Fleet with the rank of naval commander to become chief of the operational department of the Chechen separatists' general staff. ${ }^{9}$

In 2002, the command of the Pacific Fleet responded to reports of this plan to hijack a submarine by claiming that security at Russian military nuclear facilities was adequate and that the planned hijacking would have failed in 1995. "This could happen only in a foreign fantasy-action movie. In reality, it is a doomed plan," a spokesman for the fleet said. ${ }^{10}$ Yet, two years after Khasukhanov's plan was supposed to have been implemented, a single sailor managed to take hostages and lock himself up in a Russian nuclear submarine in the most dangerous case of attempted maritime terrorism in Russia, which will be discussed in greater depth below. Dudayev's archive also contained plans to blow up installations at nuclear power stations, military airfields, and oil refineries. ${ }^{11}$

Outside Chechnya, it has been Dagestani-based terrorist groups that have been most active in the North Caucasus. These groups staged two horrendous attacks in the Caspian Sea town of Kaspiisk targeting servicemen of the local unit of the Border Guard Service's coast guard branch and general military personnel in another. In 1996 they bombed a residential complex in Kaspiisk, destroying an entire section of the complex, which housed mostly servicemen of the local Coast Guard unit and their families. The

7 The Pacific Fleet operates no nuclear-powered ballistic missile submarines (SSBNs), but it still has a number of nuclear powered submarines, including those that can carry nuclear torpedoes.

8 Russian State Television, 26 April 2002, transcribed by BBC Monitoring on 26 April 2002. No other media reported this information, however.

9 "Nachalnik Operativnogo Shtaba Maskhadova Gotovil Plan Zakhvata Rosiiskoi Atomnoi Podlodki (Chief of Maskhadov's Operational Staff Was Preparing a Plan to Hijack Russian Atomic Submarine)," RIA-Novosti (25 April 2002).

10 "Komandovanie TOF: Chechenskim Boevikam Ne Pod Silu Zakhvatit Podlodku (Command of the Pacific Fleet: Chechen Rebels Are Incapable of Hijacking a Submarine)," RIA-Novosti (5 February 2002); available at www.lenta.ru/vojna/2002/02/05/submarine/.

11 "V Chechne Nashli Plan Zakhvata Rossiiskoi Lodki (Plan to Hijack a Russian Submarine Found in Chechnya,)" Lenta.ru (4 February 2002); available at www.lenta.ru/vojna. Also reported in "Nachalnik Operativnogo Shtaba Maskhadova Gotovil Plan Zakhvata Rosiiskoi Atomnoi Podlodki (Chief of Maskhadov's Operational Staff Was Preparing a Plan to Hijack Russian Atomic Submarine)," RIA-Novosti (25 April 2002). 
blast killed sixty-seven people, including twenty-one children. The same Caspian Sea town saw these Dagestani-based networks bomb a military parade in May 2002, killing 43 and injuring 170, many of the victims being spectators and their children.

Factions of these networks in North Caucasian republics of Ingushetia, Karachayevo-Cherkessia, and Kabardino-Balkaria have also displayed the capability to plan and execute complex attacks, such as seizures of urban areas accompanied by killing of military and law-enforcement personnel, with assistance of corrupted or ideologically converted police officers. The Ingush-based faction has been so successful in such attacks that the Chechen warlord Doku Umarov, who is the current leader of the terrorist and insurgency networks in the North Caucasus, has appointed Magomed Yevloyev, leader of the Ingush terrorists and insurgents, to the post of the "Commander of the Caucasian Front" of the forces fighting to establish a caliphate in the Northern Caucasus and other parts of Russia with sizeable Muslim populations.

\section{Accomplices and Allies of North Caucasus-based Networks}

International Terrorist Organizations and Groups of Militants that Support Secession from Russia. The North Caucasus-based terrorist networks - and the Chechen faction in particular-have been in close contact with foreign militant Islamists, including those groups that resort to terrorism. The best-known successful act of what Russian authorities have described as maritime terrorism - the seizure of a ferry with Russian passengers on board off the Turkish coast - was carried out in the name of Chechnya's separatist cause. Muhammad Tokcan, a Turkish citizen of Chechen origin, and his armed supporters (who included Turkish citizens of Abkhaz origin as well as ethnic Chechens) hijacked the Avrasya ferry on the Black Sea and took more than two hundred hostages in 1996. Tokcan threatened to blow up the ferry, which was not far away from the Bosporus Strait, which is only half a mile wide at its narrowest point, demanding an end to Russian military efforts to end Chechnya's separatist bid. The hijackers eventually surrendered after a four-day standoff and were subsequently imprisoned, but two of them, including Tokcan, later escaped while others were released under an amnesty law. ${ }^{12}$

Apart from maintaining ties with militant representatives of North Caucasian diasporas abroad, the Chechen-based terrorist and insurgent networks have also maintained links with Al Qaeda, which has expertise in the field of maritime terrorism. Osama bin Laden has been actively involved in the terrorist insurgency in Chechnya since 1995, sending Al Qaeda agents to the North Caucasus and sponsoring Chechen rebels, according to a declassified U.S. intelligence report. ${ }^{13}$

Bin Laden sent the Jordanian-born warlord Khattab and several instructors to Chechnya in 1995 to set up terrorist training camps, according to a U.S. Defense Intel-

12 Interestingly, Tokcan then led another group of hostage-takers who seized 120 tourists and staff in a Turkish hotel in 2002, this time to protest against Russia's second military campaign in Chechnya. He was subsequently sentenced to twelve years in prison.

13 The document was released by Judicial Watch, a U.S. public corruption watchdog, in 2004. 
ligence Agency report. Bin Laden has also met several times with militant Islamists from Chechnya and Dagestan and "settled the question of cooperation-agreeing to provide 'financial supplies' to Chechen militants.",

U.S. intelligence agencies once estimated that as many as one hundred Al Qaeda militants were present at the now defunct bases of Chechen rebels in Georgia's troubled Pankisi Gorge. The FBI also believes that such ties have existed between Al Qaeda and terrorist groups in the Caucasus. ${ }^{15}$ Furthermore, there were reports of Chechens fighting on Al Qaeda's side in Afghanistan. ${ }^{16}$ More recently, Russian security services and law-enforcement agencies announced in October 2008 that they had foiled plans by the chief of the North Caucasus-based terrorist networks and Al Qaeda's lieutenant in the region to organize terrorist attacks in the area where Russia is to host the 2012 Olympic Games. The Chechen warlord Doku Umarov and a certain Moganned, Al Qaeda's "emissary" in the region, have plotted terrorist attacks in the Black Sea resorts of Sochi and Anapa, the director of the Federal Security Service, Nikolai Bortnikov, told the sitting group of the National Counter-Terrorist Committee on 14 October 2008. Bortnikov said Umarov and Moganned had planned to use powerful homemade bombs for the foiled attacks in Sochi and Anapa. Sochi, which is to host the Winter Olympic Games, has become a potentially attractive target for terrorist groups ever since it was picked to host the Olympics. This city is vulnerable to terrorist attack,

14 “U.S. Report Links Bin Laden, Rebels," Moscow Times (22 November 2004). In addition to Khattab, several other senior figures in the Chechen-based groups are probably tied to Al Qaeda. One was Abu Dzeit, a Kuwaiti national and suspected Al Qaeda liaison who was killed by Russian security forces in February 2005. A video purportedly showing Basayev preparing for the 2004 Beslan school attack shows Abu Dzeit sitting next to Basayev. "Video Apparently Shows Basayev Planning Attack," Associated Press (1 September 2005). Also, a Jordanian named Abu Majahid, who the FSB believes to have arrived in Chechnya in 1992 and served as an emissary of Al Qaeda, was the organizer of foiled chemical attacks in cities in the North Caucasus in 2005. "FSB Says Major Terror Attacks Foiled," Moscow Times (6 May 2005).

15 "Although Al Qaeda functions independently of other terrorist organizations, it also functions through some of the terrorist organizations that operate under its umbrella or with its support, including: the Al-Jihad ... and the Chechen region of Russia." J.T. Caruso, Acting Assistant Director, Counter Terrorism Division, Federal Bureau of Investigation, "Statement for the Record on Al Qaeda International Before the Subcommittee on International Operations and Terrorism Committee on Foreign Relations," United States Senate, Washington, D.C., 18 December 2001; available at www.fbi.gov/congress/congress01/caruso121801.htm.

16 Two Chechen members of Al Qaeda were killed in a gun battle with Pakistani troops in Azam Warsak, a remote tribal area of Pakistan bordering Afghanistan on 26 June 2002, unidentified Pakistani officials said. The same area saw Pakistani security officials capture a Chechen, identified as Muhammad Yahya, also in June, the officials said. M. Ismail Khan, "10 Soldiers, Two Fugitives Killed: Al-Qaida Hideout in Tribal Area Raided," Dawn (27 June 2002). 
given its proximity to the North Caucasus and Georgia's separatist province of Abkhazia, which is regularly rocked by assassinations and bombings. ${ }^{17}$

North Caucasus-based terrorist networks can count on Al Qaeda to share expertise with them if they decide to plan and execute an act of maritime terrorism, since $\mathrm{Al}$ Qaeda has successfully carried out acts of maritime terrorism in the past. Operatives and/or allies of Al Qaeda have been responsible for the bombings of the U.S. Navy ship Cole and France's Limburg tanker. The network has also designed attacks on a wide range of Western maritime targets, including military vessels, oil tankers, and cruise ships, according to information from Abd Al Rahman al Nashiki, the alleged organizer of both attacks and an Al Qaeda member. ${ }^{18}$

In addition to developing maritime and land-based conventional terrorism capabilities, Al Qaeda has sought to acquire expertise in nuclear weaponry. ${ }^{19} \mathrm{Al}$ Qaeda has tried to acquire a ready-to-use nuclear bomb or to develop one, and has considered striking a deal with members of Russian organized criminal groups. ${ }^{20}$ North Caucasus-

17 In the past, North Caucasus-based terrorist groups have enjoyed the cooperation of their compatriots when plotting attacks in Moscow.

18 Ali M. Koknar, "Maritime Terrorism: A New Challenge for NATO," IAGS Energy Security, published by the Institute for the Analysis of Global Security (24 January 2005); available at www.iags.org/n0124051.htm..

19

George Tenet, Director of the Central Intelligence Agency, stressed in testimony given on 6 February 2002 before the U.S. Senate Select Committee on Intelligence, that terrorist groups worldwide have ready access to information on chemical, biological, and even nuclear weapons via the Internet, and that "we know that Al Qaeda was working to acquire some of the most dangerous chemical agents and toxins." According to Tenet, documents recovered from Al Qaeda facilities in Afghanistan showed that Bin Laden was pursuing a sophisticated biological weapons research program, and that the U.S. believed that Bin Laden was seeking to acquire or develop a nuclear device. Moreover, he added, "Al Qaeda may be pursuing a radioactive dispersal device-what some call a 'dirty bomb."” Quoted in Karl A. Lamers, "Draft Report on Arms Control and the Transatlantic Partnership After September 11," Political Sub-Committee on Transatlantic Relations, NATO Parliamentary Assembly (3 May 2002); available at www.nato-pa.int/publications/comrep/2002/av-112-e.html. See also the Deputy Director for National Intelligence (DDNI) report on the Acquisition of Technology Relating to Weapons of Mass Destruction and Advanced Conventional Munitions (2006): "Al Qaeda and other terrorist groups show continuing interest in developing chemical and biological capabilities for use in attacks against Western targets."

20 "We also believe that (Al Qaeda leader Osama) bin Laden was seeking to acquire or develop a nuclear device," George Tenet, Director of the Central Intelligence Agency, told hearings at the U.S. Congress in February 2002. In his testimony, Tenet refrained from disclosing where al Qaeda operatives could be shopping for such technology. "Worldwide Threat-Converging Dangers in a Post 9/11 World," testimony of the Director of Central Intelligence George Tenet before the Senate Select Committee on Intelligence, 6 February 2002. Al Qaeda may be trying to acquire nuclear weapons and weapons-grade materials in Russia through local organized crime gangs, the Washington Times reported on 8 October 2002, citing a source in the U.S. defense community. Bill Herz, "U.S. says Al Qaeda exploring Russian market for weapons," The Washington Times (8 October 2002). 
based terrorists hope that Al Qaeda will supply them with nuclear weapons for the " $\mathrm{ji}$ had against the infidels" if it manages, for instance, to topple the government of Pakistan, given the close ties between Al Qaeda and the North Caucasus-based networks and the convergence of their goals in building a caliphate.

Organized Crime. The North Caucasus-based networks have established tactical alliances with organized crime groups, primarily those that have been formed by natives of the North Caucasus across Russia. ${ }^{21}$ Such ethnically-oriented organized crime groups operate in many major Russian cities, including ports. In some instances, natives of Chechnya and other North Caucasian republics involved in ethnic crime rings outside the North Caucasus have returned to their homeland to fight on the separatists' side or vice versa. Such gangsters can potentially take advantage of established criminal channels to help the North Caucasus-based radical separatists acquire nuclear, biological, or chemical components and organize terrorist acts. ${ }^{22}$ Some organized crime gangs and terrorist groups have already begun to merge. In one instance, an alleged Chechen criminal was even found to have access to so-called "closed settlements" inhabited by the personnel of a Russian nuclear production facility.

An authoritative RAND study suggests that, while terrorists and organized crime figures are collaborating on land, there is little evidence that terrorists and piracy syn-

21 The Chechen organized crime groups have been among the largest and most influential in the Moscow area. But even those ethnic Chechens who were not identified by police as members of organized crime groups would help their compatriots plotting terrorist attacks. In October 2004, Russian media reported that Ruslan Elmurzayev, an ethnic Chechen and an employee of a Moscow bank, was one of the main organizers of the Dubrovka theater attack, and that it was financed through loans from his bank. Citing sources close to the investigation, the $I z-$ vestia newspaper reported that Elmurzayev had provided funds to purchase the minibuses that the attackers drove to the theater, as well as to house them and to buy forged passports. The Moscow City Prosecutor's Office has identified Elmurzayev, who headed the economic security department of Prima Bank, as one of two organizers of terrorist attacks in Moscow in the fall of 2002, including the Dubrovka hostage-taking. Carl Schreck, "Prima Bank Linked to Dubrovka Attack," Moscow Times (27 October 2004).

22 The Federal Service of the Tax Police estimated that most of the financing for Chechen rebels comes from Chechen organized criminal groups, which controlled more than 2000 private companies and banks across Russia in 1999. Rossiiskaya Gazeta quoted the deputy director of this service, Aslanbek Khaupshev, on 20 November 1999 as saying that dozens of companies that Chechens control in Moscow alone were involved in laundering money, some of which went to finance Chechen separatism. One scheme provided for oil to be shipped from primitive refineries in Chechnya to be illegally sold through a firm in neighboring Dagestan. The refineries were owned by Chechnya-based warlords Shamil Basayev and Khattab. By the end of 1999, the tax police had ruptured "illegal channels of financing" that were set up by Chechen organized crime groups in the Primorskii Krai, Astrakhan, Novgorod, and Lipetsk regions. The police also exposed twelve companies owned by militant Islamists, a group Russian authorities often describe as Wahhabis in KarachayevoCherkessia. Timofei Borisov, "Ekh Dollary, Da Na Tarelochke (Dollars on the Plate)," Rossiiskaya Gazeta (20 November 1999). 
dicates are collaborating. ${ }^{23}$ According to the study, their interests may conflict, and thus hinder collaboration, since pirates depend on steady commercial activities in the waters where they operate, while terrorists often seek to cause maximum damage and disruption. However, one could argue that pirates can still be contracted for hijacking by terrorists who may keep the pirates in the dark about their real attentions. Also, some terrorist and militant groups, such as the Sri Lankan LTTE, have been involved in classical organized crime activities (such as illicit trafficking) to finance their activities (until its forces were effectively destroyed by Sri Lankan government troops in the spring of 2009, the LTTE had a fleet of ten ocean-going freighters). ${ }^{24}$ And Al Qaeda itself has owned and/or controlled somewhere between fifteen to twenty-three freighters sailing in the Mediterranean, Indian, and Pacific Oceans, according to estimates of the U.S. and Norwegian intelligence agencies. ${ }^{25}$ According to the Russian Navy's assessment, the "line between piracy and maritime terrorism has already become blurred," and the challenge of fighting piracy with that of fighting terrorism should be bundled together. ${ }^{26}$

Rogue Insiders and Unsuspecting 'Helpers.' Investigations of the 2002 Dubrovka Theater hostage-taking and other suicide attacks revealed that members of these North Caucasus-based terrorist groups do not hesitate to solicit logistical and other assistance from rogue or unsuspecting natives of their home regions living outside the North Caucasus. Every large Russian city has a sizeable diaspora of natives from this region. The vast majority of these Caucasian expatriates would never knowingly assist terrorists, but that does not mean that they cannot be unwittingly manipulated, particularly through their willingness to offer aid to their exploited relatives and compatriots. In one instance, Chechnya-based terrorists even claimed to have inserted a shakhid (suicide bomber) on a Russian atomic submarine. Soon after the sinking of the Kursk submarine in August 2000, the separatists claimed that the submarine was sunk by a Dagestani shakhid, but produced no proof. Law enforcement officials have denied that either of the two ethnic Dagestanis on board the Kursk could have done anything de-

${ }^{23}$ Michael D. Greenberg, Peter Chalk, Henry H. Willis, Ivan Khilko, David S. Ortiz, Maritime Terrorism, Risk and Liability (Santa Monica, CA: The RAND Center for Terrorism Risk Management Policy, 2006).

24 Koknar, "Maritime Terrorism: A New Challenge for NATO."

25 "What Al Qaeda Can Do with a Terror Navy," World Net Daily (October 2003), cited in Koknar, ibid.

${ }^{26}$ From a 29 March 2008 statement issued to the author by the Russian Navy in response to his written questions on Russia's response to maritime piracy and terrorism for a newspaper article. 
liberate to sink it. ${ }^{27}$ The official investigation into the deadly accident revealed no traces of sabotage.

Clearly, those working at naval and other maritime facilities have the best opportunity to hijack vessels. Such crimes are more difficult to prevent, as insiders have the most thorough knowledge of the facilities' vulnerabilities and can take advantage of the trust that they enjoy among their colleagues. The most serious type of insider threat is posed when an insider conspires with outsiders.

Dangerous Insiders. While there have been no publicly known cases of subversion or sabotage at Russian naval and maritime facilities, there have been several instances when servicemen have been led to commit a crime for profit. Some officers and defense industry workers have already chosen to try to "earn" thousands of dollars from one single theft. This conforms to the findings of British nuclear security expert Gavin Cameron that the overwhelming motivation for most insider crimes committed by servicemen was a desire for individual financial gain. ${ }^{28}$

In the 1990s, when the Chechen rebel Khasukhanov allegedly planned to hijack an atomic submarine with nuclear weapons onboard, security at even some of the nuclear facilities of the Russian Navy was so lax that stealing uranium was easier than taking potatoes in Russia at one point, according to a Russian military investigator. This investigator probed the theft of four kilograms of highly enriched uranium (HEU) by the Russian Navy officer Alexei Tikhomirov in November 1993. ${ }^{29}$ Another theft of weapons-usable nuclear material occurred at a Russian naval facility in 1993. In July of that year, 1.8 kilograms of 36 percent-enriched HEU was stolen by two naval servicemen from the Andreeva Guba naval base near Russia's Norwegian border. ${ }^{30}$

Such nefarious insiders will most likely refuse to cooperate with terrorists, as their motivation is personal financial gain instead of redress of political grievances. But they

27 There were two employees of Dagestan's Dagdiesel plant on board of the Kursk when it sank in an accident that was triggered by an explosion of a faulty torpedo. Dagdiesel designed propulsion systems for the Shkval torpedoes carried by Russia's Oscar-II class nuclear submarines, to which the Kursk belonged. Employees of this enterprise regularly attended test firings of torpedoes from Russian atomic submarines. Another native of Dagestan was also on board the submarine as a staff torpedoman. Anna Badkhen and Simon Saradzhyan, "Investigation Opened into Sinking of Kursk," The Moscow Times (25 August 2000); available at www.themoscowtimes.com/stories/2000/08/25/013.htm.

Gavin Cameron, "Nuclear Terrorism: Reactors \& Radiological Attacks After September 11," paper presented at the Symposium on International Safeguards: Verification and Nuclear Material Security, Vienna, Austria, 29 October-2 November 2001. Oleg Bukharin and William Potter, "Potatoes Were Guarded Better," Bulletin of the Atomic Scientists (May/June 1995); available at www.nti.org/db/nistraff/1995/19950880.htm.

Matthew Bunn, The Next Wave: Urgently Needed New Steps to Control Warheads and Fissile Material (Washington, D.C.: Carnegie Endowment for International Peace, 2000); available at http://belfercenter.ksg.harvard.edu/publication/1753/next_wave.html. The two servicemen were sentenced to five years and four years in prison, respectively, in November 1995. Mikhail Kulik and Vladimir Orlov, "Uranovaya Krazha: Istoriya Guby Andreeva, (Theft of Uranium: History of Guba Andreeva)," Moskovskiye Novosti (October 1995). 
could be kept in the dark about the real intentions by the terrorists, who can pose as gangsters with criminal rather than political intentions. There has been one reported case in which a serviceman at a key facility was in contact with such networks. In October 2002, a Kalininskaya nuclear power plant guard was arrested on the suspicion that he may have supplied information about the plant to Chechen separatists.

In another instance, an opportunistic insider agreed to commit an act for money that investigators and prosecutors classified as terrorism, according to the Federal Security Service (FSB). Igor Senin, the deputy mayor of Zaozyorsk - a closed military town in northern Russia - was arrested by FSB agents in April 2006 and subsequently charged with plotting a terrorist attack off the coast of the Murmansk region, near the Kola Peninsula. The FSB issued a statement to assert that Senin had planned a bombing of an oil tanker in the Kolsky Bay in hopes of causing an environmental catastrophe. The official had planned to use a homemade bomb to blow up the tanker Teider in an act that would have caused at least forty metric tons of oil products to spill into the ocean, polluting at least five square kilometers of the sea surface. Senin was in fact a middleman between an unidentified client, who wanted to cause an oil spill for unknown reasons, and those who were to carry out the foiled attack, which prosecutors estimated would have caused some USD 26 million in environmental damage. The client gave Senin USD 100,000 to organize the attack. The official stood trial in 2007 on charges of having attempted to organize a terrorist attack, and was sentenced to over three years in prison by the Murmansk Regional Court.

Rogue Elements Within Law Enforcement. The corruption and ideological conversion of law enforcement officers by extremists in the North Caucasus has emerged as a major security threat, as the investigations of many major terrorist attacks have unearthed cases of corrupt or ideologically driven police officers who have assisted the attackers. Neither the boosting of passive defense measures nor increased preventive strikes against militant hideouts will succeed in curbing domestic terrorism if the Russian authorities fail to take serious action to root out the corruption that plagues the country's law enforcement community, and that has already evolved into a major threat to Russia's national security.

There have been numerous instances where the cupidity of law enforcement officers has enabled terrorist attacks to proceed. For example, in June 1995 militants bribed their way into the southern Russian town of Budyonnovsk to take hundreds of hostages there in what became the bloodiest terrorist act Russia saw in the 1990s. Back then, Chechnya's most notorious warlord, Shamil Basayev, boasted how he had paid off Russian traffic police to gain safe passage through checkpoints outside Budyonnovsk to seize a local hospital. Years later, the Russian leadership is still struggling to cope with the threat that corrupted officials and turncoats pose.

The situation is particularly alarming in Ingushetia, where a senior detective in the Ingush police's internal investigations department used his security ID to sneak Basayev in and out of Ingushetia ahead of the attacks in June 2004 that killed over two hundred people. In 2003-04, Officer Bashir Pliev drove Basayev to Ingushetia in his own car and tipped him off to planned police raids, while at the same time helping him 
to deliver weapons. ${ }^{31}$ Perhaps the highest-ranking of the alleged turncoats apprehended thus far also served in Ingushetia. Daud Korigov, who served as the republic's interior minister from 1997-98, offered rebels the use of a house he owned in the Chechen capital of Grozny, where hostages were held captive. ${ }^{32}$

Ingushetia has been so rife with corruption and ideological conversion of law enforcement officers that Dmitry Kozak, then-envoy of the Russian president to the Southern Federal District (which includes the North Caucasus) in 2007 publicly accused top police commanders of turning a blind eye to the collaboration of police officers with rebels. He then had the top leadership of the police force in the entire republic fired and replaced with individuals from outside the North Caucasus.

There have also been cases in which Chechen extremists would either change their identities or surrender in order to join pro-Moscow police forces in order to obtain information to feed to their accomplices, or even to participate in attacks staged by the terrorist groups. ${ }^{33}$

And the conversion of law enforcement officials has not been limited to the North Caucasus. One officer, Shamil Khazhiev, even quit his post in the police force of the central Russian republic of Bashkortostan in 1999 and resettled in Afghanistan, desiring to live in a society ruled by strict Sharia law. In another case, a Russian court convicted Murat Shavayev for using his Justice Ministry credentials to assist Nikolai Kipkeyev, the organizer of the deadly suicide bombing outside the Rizhskaya metro station in Moscow in August 2004. ${ }^{34}$

While most cases of police officers joining forces with extremists for either religious or opportunistic reasons have occurred in the North Caucasus region, the corrup-

31 Irina Khalip, "Provodnik Basayeva: Im Okazalsya Sotrudnik Otdela Sobstvennoi Bezopasnosti MVD Ingushetii," Novaya Gazeta (18 August 2004).

32 Korigov was even reported to have been present when the rebels were holding captive Vyacheslav Izmailov, a former army major working on commissions to resolve kidnappings in Chechnya. Burt Herman, "Former Cop Allegedly among Russia School Attack Masterminds, One of Many Turncoats in Law Enforcement," Associated Press (16 September 2004).

Policemen have been repeatedly caught trying to sell arms to extremists, while cases of policemen letting vehicles pass without proper examinations and issuing fake passports or residence registrations in exchange for cash payoffs are reported almost monthly. A case in point came when several policemen were arrested for helping Russia's most wanted man, rebel warlord Shamil Basayev, slip in and out of the North Caucasus republic of KabardinoBalkaria last year. Basayev-whom investigators believe to have ordered both the Beslan hostage-taking raid and the June raid on Ingushetia-lived in a private house in the republic's town of Baksan for an entire month. Simon Saradzhyan, "Law Enforcement Turncoats, Russia's Bane," ISN Security Watch (2005).

34 Shavayev is an ethnic Balkar, while Kipkeyev was an ethnic Karachai. Balkars, who mostly reside in the North Caucasian republic of Kabardino-Balkaria, and Karachais, who mostly reside in the North Caucasian republic of Karachayevo-Cherkessia, are closely related. Militant Islamism has been running strong in both republics, with members of Karachai networks convicted of bombing apartment buildings in Moscow. 
tion of law enforcement officials and employees of other government agencies remains a nationwide phenomenon that has allowed terrorist groups to strike Russian cities hundreds miles from their bases. A Moscow policeman was sentenced in February 2004 to seven years in prison for registering Luiza Bakueva in Moscow in 2002 in exchange for a bribe. Having registered in Moscow, Bakueva participated in the hostagetaking at Moscow's Dubrovka Theater in October 2002 (the so-called Nord-Ost attack). ${ }^{35}$

Disgruntled Insiders. When it comes to agents of maritime terrorism, it is a disgruntled insider rather than a North Caucasus-based terrorist that has come closest to committing an act of terrorism on board of a nuclear naval vessel belonging to Russia. In 1998, a young Russian sailor, Alexander Kuzminykh, locked himself in one of the fleet's nuclear-powered submarines, threatening to blow it up. Nineteen-year old sailor Kuzminykh crept out of his cabin at night to kill six fellow servicemen before taking two other hostages inside the Akula-class hunter-killer submarine, which was docked at the fleet's Skalisty base near Murmansk. Kuzminykh then locked himself and the two hostages in the submarine. Kuzminykh subsequently shot both hostages dead and repeatedly threatened to start a fire on board in order to detonate torpedoes from the nuclear submarine. Responding to this threat, Northern Fleet spokesman Sergei Anufriyev said the submarine's nuclear reactor was shut down, and there was no possibility Kuzminykh could have either blown up or sunk the submarine. He said the submarine's automated fire-extinguishing systems would put out any flames set by the sailor. He also said it would take an experienced officer to activate the submarine's torpedo detonators. Yet nearby warships and submarines were evacuated, as FSB commandos remained unable to get to Kuzminykh until he shot himself inside the submarine, separated from the agents by a 10 -cm-thick steel hatch.

It was later revealed that the sailor might have been mentally disturbed. His mother told Northern Fleet officials that her son had suffered from some kind of mental disorder when he was a child. The young man had also enjoyed inhaling intoxicants when a schoolboy, and was fond of graphically violent movies and books. ${ }^{36}$ Since this incident, Russian authorities have significantly improved the recruitment and monitoring of personnel deployed on naval nuclear vessels and facilities to weed out disgruntled insiders. For one, all of Russian submarine crews - including those boats carrying SLBMs as well as other atomic-powered vessels - are now being manned only with professional sailors, with conscripts having been removed from service. The screening of candidates for positions as professional sailors needs to be improved, however, as

35 Another such case has been heard in a Kislovodsk court. This court sentenced a local traffic policeman, Stanislav Lyubichev, to four years in prison for letting a truckload of explosives - six metric tons of hexogen, to be exact - pass through a checkpoint in 1999 with no questions asked. The explosives were later used to blow up apartment buildings in Moscow, killing hundreds of people in September 1999.

36 Simon Saradzhyan, "Sailor Kills Himself After Standoff in Sub," The Moscow Times (15 September 1998); www.themoscowtimes.com/stories/1998/09/15/015.html. 
evidenced by the case when a "drunken curious sailor" set off the fire safety system on a Russian nuclear submarine that killed twenty people in November 2008. ${ }^{37}$

Ultranationalists. The recent conviction of a Russian nuclear industry worker and several ultranationalist skinheads for bombing attacks, which are felt to have been primarily motivated by racial hatred, demonstrate that some violent ultranationalist groups and individuals in Russia are increasingly adopting methods used by terrorist groups. There are anywhere between 20,000 and 60,000 members of skinhead and other ultranationalist groups in Russia. Of those members of these groups who are violent, most stick to street weapons, such as knives, chains, and iron bars. However, some of these groups have begun to expand their arsenal to include more lethal weapons, such as explosives and even mercury. For instance, in 2007, a group of ultranationalists in the Siberian city of Tomsk was convicted of terrorism and inciting ethnic hatred for a series of attacks, including setting up a booby trap under an anti-Semitic poster and spilling mercury in a restaurant owned by a Jewish businessman.

In March 2007, six members of a skinhead group were detained in Russia's maritime capital of St. Petersburg on suspicion of having been responsible for the bombing of a McDonald's restaurant out of hatred for Americans as well as in honor of ultranationalist leader Dmitry Borovikov, who was shot dead by police in 2006. Members of Borovikov's group had been charged with killing several dark-skinned foreigners. They also acquired mercury and planned to spray or spill it to contaminate targeted facilities. The total number of these young extremists who regularly attack dark-skinned natives of the Caucasus, Asia and Africa in St. Petersburg has been put between 10,000 and $15,000 .^{38}$

37 The Russian daily Zhizn reported on 13 November 2008 that sailor Dmitry Grobov had testified that he had pushed a button to activate the fire-extinguishing system, which puts out fires by releasing deadly Halon gas, because he was curious. "I did it out of curiosity," the daily quoted the sailor as saying to the investigators. The Nerpa was undergoing tests on 8 November in the Sea of Japan when its firefighting system activated. The gas asphyxiated twenty people on the sub, and an additional twenty-one sailors were hospitalized. 167 people on board were not injured, according to the Navy. Upon his arrest, Grobov was examined by the doctors, who found him to be mentally healthy, according to Zhizn. Grobov's comrades describe him as a calm individual and remain perplexed about why he would have activated the system, the daily reported. According to investigators' "preliminary lead," Grobov had pushed the button because he was drunk. There was alcohol stored on board of the submarine, and Grobov (along with two other sailors who were on duty) had been drinking it, according to Zhizn.

38 These figures were given by the Moscow Bureau for Human Rights on 17 April 2005. St. Petersburg police, for their part, have registered more than 1,200 members of eighteen skinhead groups active in the city (see www.fontanka.ru/131388). In an interview on 25 May 2005, Vladimir Pribylovsky of the Moscow-based Panorama think tank put the number of skinheads in St. Petersburg as high as 8,000-10,000. This number includes between 1,000 and 2,000 active and motivated followers of the movement, while others sympathize with it and join its actions "opportunistically." 
Also in 2007, the Moscow Regional Court sentenced a former employee of a state scientific research center to eighteen years in prison for the June 2005 bombing of a Moscow-bound passenger train from Chechnya in what the verdict said was an ethnic hate crime. Vladimir Vlasov, a former employee of the Bochvar All-Russian Scientific Research Institute of Inorganic Materials, was sentenced along with his accomplice, Mikhail Klevachyov, who was given nineteen years in prison. Klevachyov is also reportedly an erstwhile employee of the former Soviet military-industrial complex, and had fought as a volunteer on the Serbian side in the former Yugoslavia.

It remains unclear whether Vlasov—a forty-nine-year-old with a Ph.D. in chemistry-had access to weapons-grade materials when working at Bochvar or when he left his job to open his own business, which specialized in selling chemical substances. He had been nurturing ultranationalist beliefs for a while, and his decision to target Chechens was not spontaneous: a search of his apartment netted literature promoting Russian racial supremacy.

Vlasov's conviction came less than a month after the director of the Bochvar Center, Sergei Vostrikov, was fired after Russia's ecological, technological, and atomic safety watchdog agency, Rostekhnadzor, reported that its inspectors had found "numerous violations" of regulations for the storage and accounting of nuclear and radioactive materials at the Moscow-based center. The Bochvar Center has participated in the development of nuclear fuel tablet technology and continues to use nuclear materials in its research to this day. Its personnel also visit nuclear fuel processing and storage facilities, such as Mayak in the Urals, which houses at least one facility for processing nuclear fuel designed and serviced by Bochvar engineers.

Of equal concern are cases in which ultranationalists who have studied technical sciences in Russian universities use their acquired knowledge to stage lethal hate crimes. A group of young men were convicted in May 2008 by the Moscow City Court of a series of hate crimes, including bombings. Among other attacks, they staged the August 2006 bombing at Moscow's Cherkizovsky market, which is primarily patronized by Asian customers. The attack killed eleven and injured forty-five. One of the attackers, Oleg Kostyrev, was a fourth-year student at the Dmitry Mendeleyev Russian Chemical-Technological University in Moscow. According to police, it was there that he acquired the diagram for the bomb used in the attack on the market, although the defendants insisted they had found the design on the Internet.

In a worrying development, prosecutors revealed during the trial that one of the leaders of the group had written a book to propagate his ideas of xenophobic violence, in which he referred to himself as a "messiah." As experience with totalitarian sects shows, their leaders' and members' rationale for actions is often rooted in religious beliefs that may justify not only violence against individual "aliens" or "non-believers," but even the pursuit of an Armageddon that can be brought by a terrorist act of catastrophic proportions, as it was the case with the Aum Shinrikyo apocalyptic cult in Japan. The fact that ultranationalist terrorists have so far limited themselves to land attacks does not preclude the possibility that they will stage sea or river operations if they see an opportunity, such as cruise ship in St. Petersburg carrying tourists of the "wrong" ethnic origin or nationality on board. 


\section{Russia’s Maritime and Freshwater Anti-terrorism Activities}

The safety and security of maritime shipping, which accounts for 60 percent of Russia's foreign trade, ${ }^{39}$ is of paramount importance to Russia. Russia's 2001-20 Maritime Doctrine describes "maritime shipments" as being of "vital importance" to the country. Disruption of these shipments by a series of terrorist attacks would come as a tangible blow to the Russian economy. Maritime shipping is also the only transportation method available for some of the far-flung Russian regions, and disruption of maritime channels to these regions would create serious problems for the local population.

Russia's water frontiers span over 46,000 kilometers, including 39,000 km of seacoast. Given this vast coastline, the volume of maritime and river transportation has steadily increased in Russia. The volume of cargo processing in Russia's seaports is expected to grow by 1.3 times between 2006 and 2010, while some 55 percent of the deadweight controlled by Russian companies will come to fly the Russian flag by $2010 .^{40}$

Russian ports processed 407 million tons of cargo in 2005, including 173 million tons of dry cargo and 223.78 million tons of liquid cargo such as oil, compared to 113 million tons in $1993 .{ }^{41}$ These volumes have been forecast to increase further, albeit this forecast will probably have to be revised because of the recent global economic crisis. The Russian government has predicted that Russian ports should be processing a total 540 million tons of cargo per year once global trade recovers. ${ }^{42}$

In addition to maritime channels, Russia also has thousands of inland waterways, rivers, and channels. These freshwater shipping lanes total 101,600 km, and facilitate shipments to sixty-eight out of Russia's eighty regions, These lanes annually transport 23 million passengers and 130 million tons of cargo, ${ }^{43}$ and some of them are choked by heavy traffic. For instance, vessels often spend two or three days passing through a 55$\mathrm{km}$ stretch of a waterway that connects the Gorodetsky dam and Nizhniy Novgorod, rather than the three or four hours that their speed would allow. ${ }^{44}$ Transportation of passengers by water will also increase by eight to ten times between 2005 and 2010 ,

39 At the same time, vessels carrying Russian flags account only for 4 percent of Russia's foreign trade shipments, according to the 2006-10 Strategy of Development of Transport of the Russian Federation, endorsed by the government in July 2006. Perhaps this explains the low level of attention given by government agencies to piracy.

40 According to the 2006-10 Strategy of Development of Transport of the Russian Federation, endorsed by the government in July 2006

41 According to the then-head of the Federal Agency of Maritime and River Transportation Alexander Davydenko's 2006 interview, “Uzkie Mesta Graydushchei Navigatsii,” Transport Rossii (December 2006).

42 According to the then-head of the Federal Agency of Martiime and River Transportation Alexander Davydenko's 2006 interview, "Na Puti k WTO, Chto Eshche Uspeem," RZhDPartner Port (January 2006).

43 Interview with Alexander Davydenko, "Uzkie Mesta Gryadushchei Navigatsii," Transport Rossii (December 2006).

44 Ibid. 
according to the 2006-10 Strategy of Development of Transport of the Russian Federation.

\section{Possible Scenarios of Maritime Terrorism}

Russia has a number of large seaports, as well as several major cities located in close proximity to seas or major rivers. Some of these population centers are not located directly on the sea but in deltas of rivers that empty into the ocean - such as St. Petersburg and Astrakhan - while others are seaports with sizeable populations, such as Novorossiysk. Yet other cities are located on the coast, but do not have large ports, such as Sochi. Sochi, where Russia is to host the Winter Olympics in 2014, is located in proximity to Georgia's breakaway province of Abkhazia, which remains volatile, with assassinations and bombings occurring regularly. Russia's own volatile North Caucasian republics are only a few hundred kilometers east of Sochi. There is a possibility that insurgents based in the North Caucasus will try to discredit Russia's assertions that the Southern Federal District, which includes both Sochi and the North Caucasus, is safe and secure and under the firm control of the authorities by staging attacks across the region, including in Sochi itself, before or during the 2014 games.

One of Russia's busiest ports is Astrakhan, which is connected to the Caspian Sea by a $160-\mathrm{km}$ channel, which is crossed by four ferry links. ${ }^{45}$ This port, where members of the North Caucasus-based networks have retreated to regroup and rest, has also been the site of potential terrorist attacks. In 2004, FSB agents foiled an attempt by terrorists to blow up a gas facility in this city.

A less busy but still important transportation lane is the Neva River, in the delta of which sits St. Petersburg, Russia's former imperial capital. St. Petersburg has seen no attacks by terrorist networks based in North Caucasus, which reflects the fact that it has no landmarks of great appeal to terrorist groups when compared to Moscow. But that is bound to change, as St. Petersburg - the hometown of Russia's two latest presidentshas begun to acquire some of the functions of a capital city. It has already become home to Russia's Constitutional Court, and the Russian leadership is also considering relocating the command of the Russian Navy there.

\section{Explosion of a Nuclear Weapon in a Port City}

According to the worst-case scenario, radical separatists based in the North Caucasus could hijack a submarine with nuclear warheads on board, as they have planned in the past. They could then try to deploy the weapons in the nearest port city and detonate them. But such an operation could be relatively easily foiled, as the hijacking of a submarine would immediately alert the authorities, while the launch of nuclear weapons would require the ability to break lock codes and other special expertise that the hijackers may find very difficult to obtain.

45 According to an interview with the then head of the Federal Agency of Maritime and River Transportation Alexander Davydenko, titled "My Naidyom Argumenty i Dlya Ministrov, i Dlya Sudovladeltsev," Gudok (8 February 2006). 
Alternatively, such a terrorist group could steal an atomic bomb and then smuggle it in a shipping container via sea routes to a major port city. Only anywhere between 8 and 30 percent of transit cargo containers are checked by the Russian customs agency, which is responsible for safety and security checks, such as screening for WMD. ${ }^{46}$ Another way to avoid checks could be to ship the bomb concealed inside a load of scrap metal. ${ }^{47}$

Casualties from the explosion of a nuclear weapon in a city would vary, depending on location and time, but we can assume that an explosion of a nuclear warhead in a city would immediately kill tens of thousands and would send panic waves across the entire continent. In 2005 the United States government conducted an exercise, involving the smuggling and detonation of a ten-kiloton nuclear device in the port of Charleston, South Carolina, the fourth-largest sea container port in North America. In such a scenario, a potential fatality count would be 10,000, while the number of those severely injured could reach $30,000 .^{48}$ And if terrorists were to smuggle a ten-kiloton bomb and detonate it in New York City's Times Square on a busy afternoon, up to one million would die, according to Graham Allison, one of the leading U.S. experts on nuclear terrorism. ${ }^{49}$

In the hypothetical scenario outlined above regarding the hijacking of a Russian nuclear submarine, after the nuclear weapon was detonated, the terrorist leaders would then try to compel the Kremlin to first pull Russian troops out of parts of the North Caucasus and then enter negotiations on establishment of an independent state in the region by threatening the authorities with another attack. As stated above, terrorists have already tried to subject the Russian leadership to nuclear blackmail. Russia's then most notorious terrorist leader-the Chechen warlord Shamil Basayev-tried to

${ }^{46}$ Interview with Alexander Davydenko, "Na Puti k WTO, Chto Eshche Uspeem," RZhD-Partner Port (January 2006).

47 "For instance, a federal official familiar with New York harbor, pointed to a scrap metal terminal in Jersey City and stated to a reporter: 'If I wanted to bring an atomic bomb into the port, I'd do it through that scrap operation." William Finnegan, "Watching the Waterfront," The New Yorker (19 June 2006). According to U.S. Army General Bruce Davis, "Nightline: Loose Nukes on Main Street," ABC News Transcripts (12 October 2005). An explosion of a twenty-five-megaton nuclear warhead over the heart of Detroit or St. Petersburg, for instance, would immediately kill anywhere between 200,000 and 2 million people, according to The Effects of Nuclear War (Washington, D.C.: Office of Technology Assessment, U.S. Congress, May 1979).

49 Graham Allison, Nuclear Terrorism: The Ultimate Preventable Catastrophe (New York: Times Books, 2004). 
blackmail the Kremlin with a crude radiological device that he planted in Moscow. ${ }^{50}$ Fortunately, the scenario involving the seizure and detonation of a Russian Navy nuclear missile is highly improbable, as functioning nuclear weapons are accorded the highest security in Russia and would be extremely difficult to steal.

\section{Explosion of a Dirty Bomb in a Port City}

In another potential terrorist scenario, radical separatists could hire organized criminals to either bribe or coerce personnel at a nuclear facility to steal weapons-grade material or spent nuclear fuel. They could also try to steal nuclear materials during transport, as there have been cases when such material disappeared during transit or in the process of being prepared for shipment. Even though North Caucasus-based separatists are not known to possess the expertise to build an atomic bomb with stolen weapons-grade material, they could still pack the spent fuel with explosives and then deploy it in a shipping container in St. Petersburg, Vladivostok, Sochi, or any other major Russian port. A dirty bomb made with 50 kilograms of spent fuel packed around 45 kilograms of conventional explosives could kill hundreds, if not thousands, although many of the deaths would occur weeks and months later from radiation exposure. ${ }^{51}$

\section{Hijacking of an Atomic-Powered Vessel with Subsequent Sabotage of its Reactor}

Another scenario could be an attempt to seize an atomic-powered vessel and sabotage its reactor. Radical separatists might place their agents as insiders on the ship's crew; take hostages; plant explosives at the reactor; and then try to coerce the Russian leadership into entering negotiations on secession of parts of the North Caucasus.

If either the terrorists or disgruntled insiders or both had managed to not only seize a nuclear-powered vessel and sabotage its reactor, but also to blow it up in the harbor of a major Russian port city, the consequences would have been disastrous. In addition to the immediate casualties, an explosion of a nuclear reactor would have long-term effects on the health of thousands, if not tens of thousands of people if it occurred in a

50 This terrorist leader of the Islamist strain began his career with threats to organize undercover attacks using radioactive, chemical, and biological materials against Moscow and other strategic sites in Russia unless peace negotiations, which began on 5 July 1995, proved successful. "We have radioactive elements, biological weapons that Russia left us," he said. The rebel commander went on to threaten that he could send a shakhid to plant uranium in a Russian city. "Putting uranium in Moscow requires one person. One person gets killed and the city dies," Basayev was quoted as saying. The July 1995 talks failed, and four months lateron 23 November 1995-a Russian TV crew found a lead container containing radioactive cesium-137, which had been planted by Basayev's men, in Moscow's Izmailovsky Park. In addition to tipping off the media, Basayev also claimed that his agents had smuggled four more such packages into Moscow, and that at least two of them contained explosives, which could be detonated at any time as dirty bombs.

51 James Kitfield, “Threat Assessment: Could Terrorism Go Nuclear?" National Journal (19 December 2001). 
major Russian coastal city. ${ }^{52}$ It would also have a psychological impact as great - if not greater - than that caused by a dirty bomb attack.

It is important to bear in mind that sabotaging modern nuclear reactors, which feature many redundant safety functions, would require profound know-how, including knowledge of which equipment would need to be destroyed to cause a reactor meltdown and where it is located. There is also no firm evidence that Chechnya-based radical separatists have such knowledge, although they have been trying to obtain it. In October 2002, a Kalininskaya nuclear power plant guard was arrested on suspicion that he may have supplied such information to Chechen separatists.

\section{Bombing of an Oil Tanker or an Oil Terminal}

As noted above, a corrupt Russian municipal official has already plotted to blow up an oil tanker off the coast of Russia's Murmansk region. Apart from this plot, there has been no publicly known attempt to cause a massive oil spill in Russia's territorial waters. However, we can discern from this incident that terrorist groups could in theory seize an oil tanker-for instance, at Russia's busy Black Sea port of Novorossiyskand blow it up. The damage of such an attack would be mostly economic and environmental. Prosecutors have estimated that the aforementioned potential spill of the oil tanker in the Kolsky Bay would have caused at least 40 metric tons of petroleum to be released into the sea, causing millions of dollars worth of environmental damage.

We could also extrapolate the economic costs from the bombing of the Limburg tanker in October 2002. The bombing contributed to a short-term collapse of the international shipping business in the Gulf of Aden and nearby waters, and caused rates among Yemeni shippers to soar by 300 percent, and reduced Yemeni port shipping volumes by 50 percent. ${ }^{53}$ Obviously, the spilling of 90,000 barrels of oil into the Gulf of Aden also caused serious ecological damage.

We can also only guess what damage the destruction of an oil terminal could cause in Russia's oil shipment hub, the Black Sea port of Novorossiysk. For instance, the 2004 attack against the oil terminal in Basra, Iraq, was carried out by suicide bombers in three inflatable boats. The attack killed two U.S. Navy servicemen and shut down the terminal for two days, causing almost USD 40 million in damage. ${ }^{54}$

\section{Disrupting the Shipping Operations of a Major Port}

Some of Russia's waterways are so clogged that the sinking of a vessel could paralyze traffic in them for protracted periods of time. As was mentioned above, the high level of congestion in the waterway connecting the Gorodetsky dam and the city of Nizhniy Novgorod makes this shipping lane exceptionally vulnerable to such a disruption,

52 This assessment is according to Vladimir Kuznetsov, a former inspector at Gosatomnadzor, a nuclear security watchdog, and author of Yadernaya Opasnost (Nuclear Danger) (2003).

53 Paul W. Parformak and Jonn Fritelli, Maritime Security: Potential Terrorist Attacks and Protection Priorities (Washington, D.C.: Report prepared for the Congressional Research Service, 9 January 2007).

54 Ali Koknar, "Maritime Terrorism: A New Challenge for NATO." 
whether due to the intentional scuttling of a ship or to the destruction of a bridge. Russian government agencies and research organizations have done no publicly available studies on what economic damage the long-term disruption of shipping on internal waterways could cause.

\section{Bombing of an Explosives Warehouse in Port}

Facilities such as fertilizer plants and industrial refrigeration warehouses could under certain conditions be turned into "weapons of mass destruction," according to a study released in Russia in 2002. ${ }^{55}$ An explosion at a refrigeration warehouse would lead to an enormous fire, which would release tons of ammonia into the air, possibly poisoning thousands of people over an area of several square kilometers, the study warned. In fact, Russia has already seen one attempt to execute such an attack. FSB agents foiled a 2004 attempt by two members of an extremist group based in the North Caucasus to blow up a gas facility in Russia's port of Astrakhan, which is located in the delta of the Volga River that flows into the Caspian Sea. ${ }^{56}$

\section{Seizure of a Passenger Vessel and Publicized Mass Execution of Those on Board}

As stated above, the hijacking of a passenger ship is the only act of maritime terrorism that has thus far been committed by groups seeking the secession of parts of the North Caucasus from Russia. That attack - the hijacking of a passenger ferry bound for Russia from Turkey by Chechen separatists in January 1996 - ended peacefully, although it could have become a highly public bloodbath in the vicinity of the heavily traveled Bosphorus Strait had the hostage-takers decided to implement their threats against the ship's defenseless passengers. Having seen that hostage taking alone failed to have any impact on the Russian government's decision making, terrorist groups contemplating the seizure of passenger ships may opt for escalation and execute their hostages instead, for maximum media exposure and public shock.

As a U.S. Coast Guard analyst noted, "in terms of the probability of something happening, the likelihood of it succeeding, and the consequences of it occurring, ferries

55 Alexander Fyodorov, ed., Terrorism in the Metropolis: Assessing Threats and Protecting Critical Infrastructure (Moscow: PIR Center, 2002).

56 The FSB press service announced that its agents managed to prevent two men from blowing up a gas distribution facility on 14 November 2004. According to the FSB, the two menidentified as Adam Sultanovich Magomadov and Adam Salmanovich Magomadov-tried to blow up the facility, but were intercepted. When detected, Adam Sultanovich Magomadov tried to offer armed resistance and was shot dead, while Adam Salmanovich Magomadov was only lightly wounded and taken into custody, according to the FSB's press service. An employee of Gazprom's branch in the Astrakhan province said that the facility the FSB was referring to was probably the local gas-processing plant, located in the region's capital of Astrakhan. 
come out at the very high end. ${ }^{, 57}$ According to an authoritative RAND study, onboard bombings present the greatest combination of threat and vulnerability among all forms of assault on ferries and other passenger vessels. ${ }^{58}$

\section{Bombing of a Dike}

Some of Russia's major dikes, which are connected to rivers, are located upstream from sizeable cities, making them potential targets for terrorist attacks. The then-head of the Federal Agency of Maritime and River Transportation Alexander Davydenko noted in a 2006 interview that there was a particularly serious "terrorist threat" to the vulnerable Khimki water reservoir, which is located close to Moscow, and where the surface of the water is 40 meters higher than the altitude of Red Square. ${ }^{59}$

In the same year, the then-head of the Federal Security Service Nikolai Patrushev told a session of the National Counter-Terrorism Committee, which he chaired, that groups of Chechnya-based terrorists had planned to stage a series of explosions at hydro-technical facilities in Russia. He said the threat was most serious in the south of Russia, at such locations as the dikes of the Volgograd and Tsimlyanski water reservoirs, as well as at facilities in the Saratov region and the North Caucasian republic of Dagestan. Patrushev said an inspection of these dikes and reservoirs has revealed that they were not sufficiently protected. "A sabotage or terrorist attack on one of these (facilities) can cause catastrophic consequences, including big human casualties and serious economic losses," Patrushev said. "This threat is very real.",60

There are some other potential scenarios for acts of maritime terrorism that should be kept in mind, and that must be taken into account in any comprehensive strategy to address maritime terrorist attacks, including:

- Ramming tankers and other ships or offshore oil and gas platforms with highspeed boats

- Bombing ships in port or underwater pipelines with underwater explosives ${ }^{61}$

- Mining of a port harbor

- Use of a small, high-speed boat to attack an oil tanker or offshore energy platform

- An attack on a port or a major coastal city with biological or chemical agents.

57 Eric Lipton, “Trying to Keep the Nation's Ferries Safe From Terrorists," The New York Times (19 March 2005), as cited in Parformak and Fritelli, Maritime Security: Potential Terrorist Attacks and Protection Priorities.

59 "My Naidyom Arguymenty i Dlya Ministrov, i Dlya Sudovladeltsev."

60 "Khorosho Zabytaya Trevoga," Vremya (8 November 2006).

61 According to a study by RAND, suspected members of Jemaah Islamiyah (JI) are known to have enrolled in scuba diving courses in the Southern Philippines run by commercial or resort diving companies, which members of the security forces widely believe have been undertaken for the specific purpose of facilitating underwater attacks. See Greenberg, et al., Maritime Terrorism, Risk and Liability. 


\section{The Russian Government's Response to Threat of Terrorism, Including Maritime Terrorism ${ }^{62}$}

Interestingly, Russia's 2001-20 Maritime Doctrine does not list terrorism among the maritime challenges that Russia faces. In addition to the classical military functions that it assigns to the Russian Navy, the doctrine requires the Navy to "create and sustain the conditions ... for the maritime economic activities of the Russian Federation in the world's oceans ... and for the presence of the Russian Federation on the world's seas." The doctrine also calls for "sufficient naval potential and its efficient use in case the use of force is needed to support the state's actions." The doctrine does declare that the sustainability and safety of "maritime shipments" is of "vital importance" to the Russian Federation.

Approaches on how to prioritize counter-terrorism activities vary from country to country, and even from agency to agency. One approach prioritizes diversity, and advocates that nations spread their counter-terrorism resources across the entire range of credible attack scenarios. Others focus these resources only on those scenarios that would cause the greatest damage, even though some of them might be less likely, since they have not been previously attempted. Russia's response overall seems to be tilted toward the first approach. Its organizational and legal response to terrorism has undergone major changes in the wake of a number of horrendous terrorist attacks, including the dramatic hostage situations at Moscow's Dubrovka Theater in 2002 and at the Beslan school in 2004.

A number of laws have been passed to improve the government's response to terrorism and toughen punishments for those convicted of planning or participating in terrorist acts. It is also hoped that these legislative changes will help to deter terrorist attacks as well. Among the measures that have been introduced is the use of the armed forces and security services to fight terrorists abroad.

If diplomatic methods of resolving a hostage crisis that involves Russian citizens abroad do not succeed, the President of the Russian Federation has the power to issue an executive order to have Russian troops conduct an anti-terrorist operation outside the borders and territorial waters of the Russian Federation. Such operations are conducted in accordance with the international treaties to which the Russian Federation is a signatory, and with the Russian Federal Law on "Countering Terrorism.",63

This law was passed by the parliament and signed into law in 2006 in the wake of the Beslan drama to significantly boost the powers of law enforcement, security, and defense agencies in fighting terrorism. This law permitted the use of the armed forces and other units to fight terrorism away from Russian soil. The law also empowers the president to decide whether and where to use armed forces against terrorists abroad.

62 This section is partially based on the chapter "Russia's System to Combat Terrorism and Its Application in Chechnya" in National Counter-Terrorism Strategies.

63 From a 3 April 2008 statement issued to the author by the Ministry of Transport of the Russian Federation in response to his written questions on Russia's response to maritime piracy and terrorism for a newspaper article. 
Among other things, this landmark law has given the authorities the right to sink and shoot down hijacked vessels and aircraft, even if the latter have hostages on board. The law is vague in both its definitions and procedures, which generates concern over whether it could be abused by authorities, especially when it comes to decisions about using force to fight terrorism when the lives of non-combatants are at stake.

The law defines a terrorist attack as a "bombing, arson or other action related to intimidation of the population and creating a threat to human lives, causing significant material damage or ecological catastrophe or other very grave consequences with the aim of illegally influencing the decision making of state authorities, self-rule bodies, and international organizations, as well as a threat of the aforementioned actions for the aforementioned aims." The vagueness of the definition of terrorism in the law allows the Russian authorities significant latitude in interpretation, which has resulted in such actions as the aforementioned conviction for terrorism of Igor Senin, the deputy mayor from northern Russia, even though he had planned to blow up a tanker to cause an oil spill.

More importantly, the law is also rather sketchy when describing whether and when the armed forces can be used to "prevent or interdict an act of terrorism" in "inner waters, territorial seas, [or on the] continental shelf of the Russian Federation as well as when providing security for national maritime navigation," including both surface and underwater. According to the law, "if maritime or river vessels do not react to commands and/or signals to stop violating the rules of the use of the waters of the Russian Federation (as well as underwater), or refuse to obey demands to stop, then weaponry of naval ships (and warplanes) of the Armed Forces of the Russian Federation are used to coerce the vessel to stop in order to eliminate the threat of act of terrorism." "If the vessel doesn't stop, doesn't obey orders and/or it is impossible to coerce the vessel to stop, and all the measures that are possible in that situation to stop it have been exhausted, and there is a real threat to human lives or an ecological catastrophe, then weaponry of the naval ships (and warplanes) of the Armed Forces of the Russian Federation shall be used to end the movement of this vessel by its destruction."

The law contains a closed, classified section that contains the regulations for how the Defense Ministry and other government agencies should deploy the armed forces in counter-terrorist operations. The law also empowers the head of the counter-terrorist headquarters that have been set up to deal with a terrorist act to decide whether and when to sink a vessel, including passenger ships. Obviously, the lack of transparency in these issues leaves policy analysts wondering whether all possible means would be exhausted, and whether the value seen in eliminating the threat posed by the hijacked vessels would outweigh the potential consequences that might ensue if the ship were allowed to sail on when the decision is made to sink it. On the other hand, the declassification of standard operating procedures in such cases would enable terrorists to plot attacks that the armed forces and security forces might be powerless to stop before it is too late because of the unique legal proscriptions set forth in the law, effectively giving terrorists the freedom to operate with impunity. In another significant development, the law also gave the lead role in fighting terrorism to the Federal Security Service (FSB) in a clear effort to centralize command over counter-terrorism activities. Previously, 
the Ministry of Internal Affairs (MVD) and FSB had shifted some counter-terrorism duties back and forth, but this effort at dividing responsibilities proved unworkable, given the number and scale of terrorist attacks in Russia. In coordination with this counter-terrorism law, the Russian president also signed a decree establishing a National Counter-Terrorism Committee (NCC) in February 2006. The president put the FSB in charge of this permanent body to coordinate the federal agencies' response to terrorism. ${ }^{64}$

While the FSB-led NCC supervises counter-terrorism activities at the federal level, it is up to the well-established Regional Counter-Terrorism Commissions to coordinate similar activities on the local level within each of Russia's more than eighty regions. These committees were set up in 1998 under the chairmanship of the governors, but in many cases they meet only sporadically, and thus have little practical impact.

While the NCC and its regional counterparts oversee routine policy making, the recently established Federal Operational Staff and regional Operational Staffs will take over once a major terrorist attack erupts, according to the 15 February 2006 decree. FSB officers will lead both the federal and regional staffs. The parallel hierarchies of the NCC and the regional commissions (which operate continually) and the federal and regional staffs (which become involved only when a crisis occurs) work together to "ensure the uninterrupted command of counter-terrorism operations," then-NCC chairman Nikolai Patrushev told the Russian media in March $2006 .{ }^{65}$ In addition to the aforementioned landmark law on countering terrorism, a number of other federal bills have been introduced to ban authorities from conducting political negotiations with terrorists, as well as to permit the confiscation of property of terrorists and outlaw handing over the bodies of slain terrorists to their relatives. ${ }^{66}$

64 Under the February 2006 presidential decree, the NCC is chaired by the FSB director and includes all the chiefs of the law enforcement agencies as well as other key ministries, including the Interior, Defense, Emergency Situations, and Justice Ministers. The top priority for the recently established committee is "drafting proposals for the president ... on formulating the state's counter-terrorism policy and perfecting legislation ... in this sphere." Paradoxically, the head of the Federal Service for Ecological, Technological, and Atomic Oversight does not sit on this committee, raising questions about whether the NCC's approach to such grave threats as nuclear, biological, and chemical weapons and WMD terrorism will be comprehensive.

66 In fact, even the bodies of suspected terrorists - such as those individuals who died during an attack by rebels on police and security facilities in the North Caucasian city of Nalchik in 2005-have been cremated, even though they never stood trial or were convicted of terrorism, which can be punished by life in prison in Russia. The de facto response has also included rounding up relatives of suspected terrorists, as was the case with relatives of Chechen rebels' late leader Aslan Maskhadov and relatives of the Beslan hostage-takers. The relatives of the latter were even brought in from Ingushetia to Beslan and encouraged to assist in negotiations. In the wake of the Beslan drama, Russia's then Prosecutor General Vladimir Ustinov proposed amending federal laws to allow taking the relatives of hostagetakers into custody as a way to put pressure on the latter. 


\section{Key Agencies' Evolving Organizational Response to Terrorism}

The Defense Ministry. Russia's Defense Ministry, as in many other countries, is taking on an increasingly prominent role in anti-terrorism operations. The fact that both the Defense Minister and the chief of the General Staff of the Armed Forces sit on the National Counter-Terrorism Committee reflects the role that Russia's political leadership would like the military to play in fighting terrorism. Defense Ministry troops regularly stage what the top commanders insist are counter-terrorism war games, but which in reality look more like simulations of full-fledged military operations to suppress widescale insurgency or separatist movements, involving both the air force and navy. The Russian-Chinese wargame of 2005 was illustrative. The exercise, which was held in China, was framed as an anti-terrorism operation, but it featured the landing of a joint force with a subsequent advance inland. Other counter-terrorism games held in Russia have featured Russian strategic bombers firing new cruise missiles to simulate strikes against suspected terrorist hideouts abroad.

But while they are prepared to game anti-terrorism operations, the Russian armed forces are reluctant to play a lead role in actual counter-terrorist activities on the ground after having been badly bloodied in their "re-conquering" of Chechnya during Russia's second Chechen war. Reflecting this reluctance, then Defense Minister Sergei Ivanov observed that to have army units fight terrorist groups is "like chasing flies with a sledgehammer." Nevertheless, Defense Ministry units continue to play auxiliary roles, such as providing air transportation and fire support, including attack planes and gunships for law-enforcement units pursuing groups of insurgents and terrorists. For instance, it was a 58th Army tank that fired on the Beslan school to eliminate pockets of resistance during the final moments of the hostage drama. Engineering groups of this army unit played a lead role in defusing the improvised explosive devices found at the school, even as FSB commandos continued to battle the terrorists elsewhere in the building. And, in spite of its reluctance to be on the front lines in fighting terrorism, the Defense Ministry may find itself in the spotlight. The new law on terrorism makes the military responsible for sinking hijacked ships and shooting down hijacked airliners.

Of course, of all the branches of the armed forces, it is the navy that bears the main responsibility for fighting maritime terrorism and piracy threats. The Russian Navy, along with the rest of the armed forces, saw its financing plummet with the disintegration of the Soviet Union. Faced with a lack of cash, the top commanders and political leadership decided to disproportionately finance their strategic nuclear forces, which they saw as the main deterrent. As a result, the naval component of the strategic nuclear triad receives more money than conventional naval forces, leaving the latter in an increasingly poor state. ${ }^{67}$ Then-commander of the Russian Navy Adm. Vladimir Kuroyedov admitted in February 2005 that the navy would have to begin "massive and

67 But even as the financing improved and the country's military budget began to grow in the late 1990s, this disproportion in financing persisted. As recently as last year, the construction of Project 955 and 955A atomic submarines consumed 70 percent of all funds allocated for construction of warships in 2007. "Kuda Idyot Voyennyi Flot," Vlast (25 February 2008). 
irreversible" decommissioning of warships after 2010, which would leave the navy with about fifty combat warships by 2020 for the country's Black Sea, Baltic, Northern, and Pacific Fleets as well as in the Caspian Sea flotilla. ${ }^{68}$ Of these, only the Northern and Pacific Fleets remain adequately ready for combat. ${ }^{69}$

As of 2003, the Russian Navy had 146 combat warships, including 70 ocean-going vessels, compared to the Soviet Navy's total of 703 (including 380 ocean-going vessels) in $1985 .^{70}$ The Russian Navy's operational capabilities on the world's seas have decreased by two-thirds since the disintegration of the Soviet Union, according to Russian naval experts' estimates.

The Federal Security Service (FSB). As was noted above, the FSB has been given the lead role in fighting terrorism in Russia. FSB officers chair the NCC and sit on this committee's regional counterparts to oversee routine counter-terrorism policy making. They are also tasked with leading the aforementioned counter-terrorism Federal Operational Staff and regional Operational Staffs in cases of terrorist attacks.

Overall, the FSB has formidable powers that allow it to investigate a wide range of different types of crimes, but is not generally held accountable for the crime rates in Russia. Therefore, the FSB can concentrate on its core missions, which include fighting terrorism. It also has better resources to tackle this threat than the police, as well as better analytical and intelligence capacities. The service has recently absorbed the Federal Agency for Government Communications and Information, which has the capacity for electronic surveillance, and the Border Guards, who are also allowed to conduct intelligence operations.

In addition, a 2006 law gave Russia's lead domestic security service the power to send its commando units abroad to strike terrorist groups and their bases. The bill, which contained amendments to fourteen different laws, including the law on the FSB, also granted this main successor to the KGB the right to go beyond sharing terrorismrelated data with foreign counterparts and operate on the territories of foreign countries. The FSB has also been legally allowed to use force outside of Russia, even though the break-up of the KGB left the FSB initially focused on domestic operations, while the overseas operations went to the Foreign Intelligence Service.

The FSB has also subsumed the Border Guard Service under its command, including its coastal guard forces. These coastal guard units are tasked with the challenge of protecting Russia's 46,000 km of water frontiers, including 39,000 km of seacoast. And, while the areas in the Far North pose few concerns to the border guard service, the seas in the Northwest and Far East along with the Caspian and Black Seas require

68 Ibid.

69 Ibid.

70 "Kuda Plyvyot VMF Rossii," V.V.Zabros (31 October 2007); available on the web site of the graduates of the Popov Naval Radioelectronics Academy, at http://vvmure1987.ru/index. php?nma $=$ catalog\&fla $=$ stat\&cat_id $=22 \&$ page $=1 \&$ nums $=103$. 
robust flotillas of the Russian equivalent of the U.S. Coast Guard to fight smugglers and poachers. ${ }^{71}$

During Andrei Nikolayev's stint as chief of Russia's border guard in 1993-97, the service expanded dramatically to acquire many ships and heavy armament, including artillery and even tanks. During this "golden era" of the 1990s, the border guards were independent, and boasted personnel strength of some 220,000 servicemen, including 195 generals (compared to a mere seventy they had while they were still part of the Soviet security monolith according to reports in the Russian press). But the ascent of a former KGB officer and ex-director of the Federal Security Service-namely, Vladimir Putin - to the presidency in 1999 signaled changes for all of Russia's so-called power agencies, and the border guard service was no exception. In 2003, Putin decreed that the border guard service would be put under the jurisdiction of the Federal Security Service.

Prosecutor General's Office. The Prosecutor General's Office and its Investigative Committee are tasked with investigating rather than interdicting terrorist incidents. The committee investigates and prosecutes all major terrorist attacks. The General Prosecutor's Office also has special departments responsible for overseeing individual lawenforcement agencies and could help to entice them to shift their focus from response and post-facto investigation to deterrence and prevention.

Interior Ministry. One of the problems exposed by the Beslan tragedy has been the failure of the Interior Ministry and other law enforcement agencies to shift the focus of its operations from responding to terrorist acts to preventing them from taking place. NCC's then Chairman Patrushev made clear at the time that preventing terrorism is one of the key institutional challenges that his committee needs to resolve as soon as possible. $^{72}$

The current focus on solving crimes, rather than preventing them, results from a flawed system that links officials' career advancement and salary increases to reported police statistics identifying what proportion of cases they have closed successfully. The Interior Ministry for years has sought to put in place a new system that would only take account of success in solving serious crimes while adding a variety of other indicators, but it is yet to materialize. Meanwhile, the Russian police continue to inflate statistics on how successful they are in solving all the crimes they register, a practice known in Russia as "chopping sticks."

On the positive side of the ledger, the Interior Ministry has established a Department for Terrorism and Organized Crime on the basis of an earlier directorate, which

71 The coast guard vessels inspected 27,000 fishing vessels in 2005, intercepting 500 Russian and foreign poaching ships to confiscate 2,400 tons of fish and seafood, according to Vice Admiral Vyacheslav Serzhanin, commander of the Coast Guard directorate of the Border Guard's Organizational Department. Serzhanin was quoted in Russian newspaper Rossiya in March 2006 as saying that most of the poaching occurs off Russia's far eastern coast and in the Caspian Sea.

Interfax-AVN (20 March 2006). 
focused on organized crime only. Such a structure places the ministry in a better position to disrupt the nexus of terrorism and organized crime as detectives who are fighting both of these threats interact with each other and share information. But, as was the case with its predecessor, and as is the case with almost all Interior Ministry branches, this directorate is focused on investigating crimes that have already occurred.

The Interior Ministry also supervises Russia's rough equivalent of the United States' National Guard, known as the Interior Troops. As noted above, officers of these troops have been supervising the Operational Control Groups to coordinate the response of all government agency personnel on the ground during the initial stages of responding to a terrorist attack under way. And although command and control functions shift to the FSB during the following stages of a response effort, the Interior Troops units remain heavily involved, providing both manpower and firepower to the security service's command centers. These Interior Troops also have special units of combat divers that can be called into action should a maritime terrorism scenario materialize.

\section{Conclusions and Recommendations}

That only one act of maritime terrorism, targeting Russian citizens and Russian assets, has been carried out and several more attempted reflects the global trend. Seaborne strikes have constituted only 2 percent of all international terrorism incidents over the last thirty years, according to the RAND Terrorism Database. ${ }^{73}$ The RAND study suggests that acts of maritime terrorism are rare because operating at sea requires specific skills in addition to those specialized competencies needed to operate a ship, such as surface and underwater demolition techniques. It also requires access to appropriate assault and transport vehicles and the ability to mount and sustain operations from a non-land-based environment. ${ }^{74}$

Yet, in spite of these difficulties, maritime terrorism should not be discounted as a negligible threat in Russia for a number of reasons. The first reason is the improvement of security at land-based military facilities. Government agencies have implemented extensive measures to harden inland targets to such an extent that the targets located on rivers and seas are becoming relatively more attractive as targets for groups that have previously considered these water targets to require too many resources and special skills to attack.

Second, the increasing frequency and importance of maritime shipments make them easier and higher-impact targets. Maritime shipping already accounts for 60 percent of Russia's foreign trade, and has been forecast to continue to grow, although the current economic crisis will probably slow down or arrest this growth. There are also large areas in Siberia where water is the only possible venue for cargo transportation, with neither roads nor railways connecting these areas to 'mainland' Russia. Also, as Russia's oil output had grown dramatically in the several years prior to eruption of the

73 See Greenberg, et al., Maritime Terrorism, Risk and Liability.

74 Ibid. 
economic crisis in Russia in the fall of 2008, so have shipments of oil in tankers from Russia, making it easier to plan an attack on such a tanker to cause a massive oil spill that would cause economic and ecological damage to Russia. And, while rebels in Chechnya have largely abstained from attacking the oil infrastructure, perhaps because they have benefited from the oil industry financially, in other parts of Russia terrorist networks have attacked facilities with the aim of inflicting economic damage, including electricity lines in the Moscow region and gas pipelines in Tatarstan.

The third reason that maritime terrorism should not be discounted, despite its rarity, is that maritime violence is no longer out of sight. The rapid development and increasing availability of technologies used to record and transmit visual and other data, ranging from personal mobile phones equipped with cameras to professional cameras mounted on media helicopters, mean that maritime targets are no longer of sight and, therefore, their value increases in the eyes of terrorists, who always seek to maximize the impact of their actions on their target audiences.

While conventional maritime attacks will be easier to execute in the future, I would argue that endemic agents of terror in Russia are more likely to attempt acts of catastrophic proportions. The terrorist networks based in the North Caucasus should have realized by now from their own experience that nothing short of catastrophic terrorist attack would coerce Russian authorities to negotiate; not even a terrorist act on the scale of the Beslan siege, in which more than one hundred children died, succeeded in forcing the Kremlin to the negotiating table. The organizer of this attack and Russia's then most notorious terrorist Basayev admitted soon after this horrendous attack that Moscow's refusal to acquiesce to his demands had come as a big surprise. He then vowed to seek "new ways" to try making the Kremlin acquiesce, in what appeared to be a veiled threat to attempt an act of catastrophic proportions. ${ }^{75}$

Basayev has since been killed, and so were the Chechen separatists" "president" Aslan Maskhadov and his successor. Meanwhile, the current leader of the Chechen insurgent and terrorist groups, Doku Umarov, is kept on the run, and his fighters' operations pale compared to the insurgency that rocked the region only a few years ago.

The Russian armed forces and law enforcement agencies are battling radical separatists on the run in the North Caucasus, trying among other things to decrease their ability to plan and execute acts of catastrophic nuclear terrorism. These efforts are slowly paying off in Chechnya, where the shift from large-scale operations by federal troops to seek-and-destroy raids by natives of the North Caucasus have significantly damaged the terrorist networks' capabilities. Meanwhile, the Russian government is continuously striving to increase security at its nuclear facilities, including both naval and civil atomic-powered vessels. These efforts serve to diminish the opportunities for inside personnel and outsiders to carry out terrorist attacks.

75 "I am trying not to cross the line. And so far, I have not crossed it," said Basayev who has been behind many of the bloodiest and scariest terrorist attacks in Russia, including Beslan, Dubrovka, suicide bombings of airliners, and planting containers with radioactive materials in Moscow. Basayev's interview with U.S. television network ABC on 28 July 2005. 
But, in spite of the successes that authorities have achieved in decapitating the insurgent and terrorist networks based in the North Caucasus, these groups are still going strong in some parts of this volatile region. They stage regular attacks, including bombings of facilities in Chechnya, Ingushetia, and Dagestan, as well as other parts of the region. These attacks demonstrate that the networks remain capable of planning and executing complex attacks - with at least some of their members prepared to die in them-while their motivation to commit acts with greater casualties and higher impact increases.

If these networks ask themselves what single event can reverse their fortunes in the fight to defeat Russia and establish an independent state in the North Caucasus, what is the single option they should focus their energy and capabilities on, the answer most likely would be a nuclear terrorist attack staged from land or water. An alliance of North Caucasus-based terrorist groups, corrupt law enforcement officials, and venal insiders would be impossible to interdict, especially if the hijackers are well organized and armed and are prepared to die, thinking they are fighting a holy war, in which they have already dehumanized the enemy and its infidel civilians and in which the reward for their "martyrdom" is paradise.

While initially skeptical in their assessment of the probability of nuclear terrorism, Russian policy makers (including the president and his top cabinet officials) have become increasingly concerned about it. "We live in a very dangerous and complicated world when the number of nuclear countries is increasing, when there is a high threat of nuclear terrorism," Dmitry Medvedev said in March 2008 ${ }^{76}$ Nikolai Patrushev, then-chairman of the National Counter-Terrorism Committee (NCC) and then-Director of the FSB, said in June 2007 that his agency is "receiving information, including information supplied by our foreign partners, on terrorists striving to gain access to weapons of mass destruction and technologies for production."77

As a result of such fears, Russian military officials say they are acting to improve the defense of Russian nuclear arsenals against terrorists. "The tasks of ensuring the reliable protection of nuclear munitions and nuclear weapons have acquired the highest level of importance in an environment of intensified threats emanating from international terrorism," stated Colonel-General Vladimir Verkhovtsev, chief of the Russian Defense Ministry's 12th Main Directorate, which is responsible for the management and security of Russia's nuclear arsenal. ${ }^{78}$ According to Lt. General Vitaly Linnik, the deputy commander of the Strategic Missile Forces, "Today, the personnel of RVSN (Strategic Missile Forces) are carrying out all necessary measures to protect their facilities from unauthorized access and possible sabotage. These measures are perfected and increased to remain adequate to threats emanating from terrorists."

Russia needs to continue to strengthen these and other lines of defense against both nuclear and conventional terrorism. Funding of these anti-terrorism efforts must remain

\footnotetext{
76 “Interview with Dmitry Medvedev," Financial Times (24 March 2008).

77 ITAR-TASS (5 June 2007).

78 Krasnaya Zvezda (26 September 2008).

79 Interfax (29 March 2005).
} 
a priority, and the expenditures must be maintained, even as the government ponders which budget expenditures to trim in the times of deepening economic crisis. However, no matter how many lines of defense are built around Russia's facilities, borders, and key terminals, these efforts will prove futile unless the nation's security culture improves and nefarious insiders are winnowed out. Russian law enforcement agencies must also be cleansed of corrupt or disloyal officials who may provide safe passage to terrorists for material gain or ideological reasons.

These agencies and security services would also be advised to acknowledge the emerging terrorist threat posed by ultranationalists armed with technical knowledge and access to hazardous materials. And, of course, these agencies should continue to keep groups on the run - no matter their political or ideological orientation - that might be interested in both nuclear and conventional maritime terrorism. Security agencies across the entire sweep of the Russian Federation's bureaucracy must diversify their counter-terrorism efforts to focus not only on jihadist groups based in the North Caucasus, as is now the case, but also on the increasing propensity for terrorism among ultranationalist groups in other parts of Russia. 


\section{Bibliography}

Allison, Graham. Nuclear Terrorism: The Ultimate Preventable Catastrophe. New York: Times Books, 2004.

Badkhen, Anna, and Simon Saradzhyan. "Investigation Opened into Sinking of Kursk." The Moscow Times (2000).

Borisov, Timofei. "Ekh Dollary, Da Na Tarelochke (Dollars on the Plate)." Rossiiskaya Gazeta (1999).

Bukharin, Oleg, and William Potter. "Potatoes Were Guarded Better." Bulletin of the Atomic Scientists (1995).

Bunn, Matthew. The Next Wave: Urgently Needed New Steps to Control Warheads and Fissile Material. Washington, D.C.: Carnegie Endowment for International Peace, 2000.

Cameron, Gavin. "Nuclear Terrorism: Reactors \& Radiological Attacks After September 11." In Symposium on International Safeguards: Verification and Nuclear Material Security. Vienna, Austria, 2001.

Caruso, J. T.. Statement for the Record on Al Qaeda International Before the Subcommittee on International Operations and Terrorism Committee on Foreign Relations. Washington, D.C.: United States Senate, 2001.

Davis, Bruce. "Nightline: Loose Nukes on Main Street." ABC News Transcripts (2005).

Davydenko, Alexander. "My Naidyom Argumenty i Dlya Ministrov, i Dlya Sudovladeltsev." Gudok (2006).

Davydenko, Alexander. "Na Puti k WTO, Chto Eshche Uspeem." RZhD-Partner Port (2006).

Davydenko, Alexander. "Uzkie Mesta Graydushchei Navigatsii." Transport Rossii (2006).

Dudayev Grozit Perenesti Voinu v Glub’ Rossii. Vecherny Chelyabinsk (1995).

Finnegan, William. "Watching the Waterfront." The New Yorker (2006): 19 June 2006.

FSB Says Major Terror Attacks Foiled. Moscow Times (2005).

Fyodorov, Alexander. Terrorism in the Metropolis: Assessing Threats and Protecting Critical Infrastructure. Moscow: PIR Center, 2002.

Gladkevich, Yury. "Poshel v Gory." Profil.

Greenberg, Michael D., Peter Chalk, Henry H. Willis, Ivan Khilko, and David S. Ortiz. Maritime Terrorism, Risk and Liability. Santa Monica, CA: The RAND Center for Terrorism Risk Management Policy, 2006.

Herman, Burt. "Former cop allegedly among Russia school attack masterminds, one of many turncoats in law enforcement." Associated Press (2004).

Herz, Bill. "U.S. says Al Qaeda exploring Russian market for weapons." The Washington Times (2002). 
Interview with Dmitry Medvedev. Financial Times (2008).

Khalip, Irina. "Provodnik Basayeva: Im Okazalsya Sotrudnik Otdela Sobstvennoi Bezopasnosti MVD Ingushetii." Novaya Gazeta (2004).

Khorosho Zabytaya Trevoga. Vremya (2006).

Kitfield, James. "Threat Assessment: Could Terrorism Go Nuclear?" National Journal (2001).

Koknar, Ali M.. Maritime Terrorism: A New Challenge for NATO. Energy Security, by the Institute for the Analysis of Global Security, 2005.

Komandovanie TOF: Chechenskim Boevikam Ne Pod Silu Zakhvatit Podlodku (Command of the Pacific Fleet: Chechen Rebels Are Incapable of Hijacking a Submarine). RIA-Novosti, 2002.

Kuda Idyot Voyennyi Flot. Vlast (2008).

Kuda Plyvyot VMF Rossii. V.V.Zabros (2007).

Kulik, Mikhail, and Vladimir Orlov. "Uranovaya Krazha: Istoriya Guby Andreeva, (Theft of Uranium: History of Guba Andreeva)." Moskovskiye Novosti (1995).

Lamers, Karl A.. Draft Report on Arms Control and the Transatlantic Partnership After September 11 In Political Sub-Committee on Transatlantic Relations. NATO Parliamentary Assembly, 2002.

Lipton, Eric. "Trying to Keep the Nation's Ferries Safe From Terrorists." The New York Times (2005).

M. Khan, Ismail. "10 Soldiers, Two Fugitives Killed: Al-Qaida Hideout in Tribal Area Raided." Dawn (2002).

Nachalnik Operativnogo Shtaba Maskhadova Gotovil Plan Zakhvata Rosiiskoi Atomnoi Podlodki (Chief of Maskhadov's Operational Staff Was Preparing a Plan to Hijack Russian Atomic Submarine). RIA-Novosti, 2002.

Parformak, Paul W., and Jonn Fritelli. Maritime Security: Potential Terrorist Attacks and Protection Priorities. Washington, D.C.: Report prepared for the Congressional Research Service, 2007.

Sanin, Grigorii, and Aleksandr Zakharov. "Konteyner Iz Izmailovskogo Parka Blagopoluchno Evakuirovan." Segodnya (1995).

Saradzhyan, Simon. "Sailor Kills Himself After Standoff in Sub." The Moscow Times (1998).

Saradzhyan, Simon. Law Enforcement Turncoats, Russia's Bane In ISN Security Watch., 2005.

Schreck, Carl. "Prima Bank Linked to Dubrovka Attack." Moscow Times (2004).

The Effects of Nuclear War. Washington, D.C.: Office of Technology Assessment, U.S. Congress, 1979. 
SUMMER 2009

U.S. Report Links Bin Laden, Rebels. Moscow Times (2004).

V Chechne Nashli Plan Zakhvata Rossiiskoi Lodki (Plan to Hijack a Russian Submarine Found in Chechnya). Lenta.ru, 2002.

Video Apparently Shows Basayev Planning Attack. Associated Press (2005).

What Al Qaeda Can Do with A Terror Navy. World Net Daily, 2003. 